\title{
MORPHOLOGICAL AND MOLECULAR MARKER SCREENING FOR DROUGHT TOLERANCE IN EGYPTIAN JEW'S MALLOW (CORCHORUS OLITORIUS L.) LANDRACES
}

\author{
Talaat Bashandy ${ }^{1}$, Abdel-Haleem A. H. El-Shaieny² \\ ${ }^{1}$ Department of Genetics, Agriculture Faculty, New Valley University, New Valley, Egypt \\ 2 Department of Horticulture, Faculty of Agriculture, South Valley University, 83523 Qena, Egypt \\ Link to this article: https://doi.org/10.11118/actaun.2021.009 \\ Received: 21. 6. 2020, Accepted: 4. 1. 2021
}

To cite this article: BASHANDY TALAAT, EL-SHAIENY ABDEL-HALEEM A. H. 2021. Morphological and Molecular Marker Screening for Drought Tolerance in Egyptian Jew's Mallow (Corchorus olitorius L.) Landraces. Acta Universitatis Agriculturae et Silviculturae Mendelianae Brunensis, 69(1): 79-89.

\begin{abstract}
Drought is the most important abiotic stress that severely affects the growth and yield of crops. The current study aimed to evaluate seven Jew's Mallow landraces (collected from different locations of Egypt) for both their response to water deficit and the level of genetic diversity among them. The water regime conditions that based on either $95 \%$ or $60 \%$ field capacity (FC) were applied after 21 days from the sowing date. Some morphological traits were measured, and the genetic diversity was evaluated by using random amplified polymorphic DNA (RAPD) marker. The results showed that the landraces differed in their responses to water deficit. All the studied agro-morphological traits were reduced under the stress condition, as well as chlorophyll content was significantly reduced. Furthermore, all the landraces accumulated the highest value (4.29) of proline at 60\% FC. According to some drought indices, L6 was the most tolerant for drought stress, followed by L4, L7 and L5, while L1 was the lowest one. On the other hand, a moderate level of polymorphism (58.6\%) was detected and a highly range of similarity relationships (0.61 to 0.84 ) were observed. Furthermore, the RAPD dendrogram was able to discriminate among the genotypes according to both their geographical and their drought tolerance capacity. The superiority of some landraces under drought stress conditions especially L6 suggested that landraces could be a beneficial tool for Jew's Mallow improvement breeding programs.
\end{abstract}

Keywords: drought, ecotypes, molokhiya, RAPD marker, leafy vegetables

\section{INTRODUCTION}

Molokhiya or Jew's Mallow (Corchorus olitorius L.) belongs to the genus of about 40-100 species in the family Tiliaceae. It is the most important and popular summer leafy vegetable in Africa, Asia and Middle East countries, especially in Egypt and Sudan. It is eaten as a fresh vegetable soup. Even though the dried leaves could be used as well, and millions of households in developing countries depend on the Jew's Mallow as a source for food. However, these leaves are a rich source of iron, protein, calcium minerals, thiamin, riboflavin, niacin and dietary fiber. Also, it contains several phenolic antioxidative compounds, polysaccharides, carotenoids and folic acid (Fawusi et al., 1984; Abou Hadid et al., 1994; Ghoneim and El-Araby, 2003; Abd-Allah, 2006; Abd-Allah and Nasr, 2006; Abd-Allah et al., 2010; Helaly et al., 2016; Ufoegbune et al., 2016). In Egypt, the total cultivated area in 2018 was 887.8 hectares $^{-1}$ with a total production of 2,172 tons and an 
average yield of 0.409 tons per hectare ${ }^{-1}$ (FAO, 2018). Water deficit is a major problem that causes a huge morphological, physiological, biochemical, and molecular changes in plants lead to many harmful effects on growth, yield and quality of plants, especially herbaceous plants (Ahmed et al., 1998; Palve and Sinha, 2005; Helaly et al., 2016; Bashandy and El-Shaieny, 2016; Wang et al., 2016; El-Shaieny, $2017 \mathrm{a}$ and $\mathrm{b}$ ).

The water percentage in leafy vegetables was ranged from 80 to $95 \%$, it is containing a lot of water quantities. In addition, their yield and quality suffer very quickly from drought. Leafy vegetables are very sensitive to water deficiency, and its yield and quality were significantly decreased in such environments. In case of the shortages occurs early in the crop's development, maturity may be delayed, and yields are often reduced. Also, when it occurs later in the growing season, quality is often reduced even though total yields are not affected (Ufoegbune et al., 2016). The world population, climate changes and pollution of natural resources of water were increased rapidly, caused limitation of water availability (Boamah et al., 2011). Furthermore, the selection of favorable genotypes with desirable traits needs to detect and check the genetic diversity and relationships among them. Molecular markers are effective and rapid method to characterize genetic diversity (Jarvis et al., 2000). Random amplified polymorphic DNA (RAPD) one of many types of DNA molecular markers that have been widely used to detect genetic variations (Williams et al., 1990). RAPD marker has been successfully performed in different plant species (Vierling and Nguyen, 1992; Menkir et al., 1997; Rocha et al., 2010; Kumar et al., 2017; Moolendra et al., 2018), as well as it has been applied in Jew's Mallow (Roy et al., 2006; Haque et al., 2007; Heikal et al., 2015; Youssef et al., 2019). Therefore, the present work was designed to study the Jew's Mallow landraces response, to different levels of soil moisture stress, to select the superior landraces that produce the greatest growth and yield under
I: List of 7 Jew's Mallow landraces used in this study

\begin{tabular}{ccl}
\hline No & Name & \multicolumn{1}{c}{ Original place of collection } \\
\hline 1 & L1 & Alexandria, Egypt \\
2 & L2 & Balat, New Valley, Egypt \\
3 & L3 & Eldakhla, New Valley, Egypt \\
4 & L4 & Esna, Luxor, Egypt \\
5 & L5 & Eddfo, Aswan, Egypt \\
6 & L6 & El-Monshaa, Sohag, Egypt \\
7 & L7 & Dandara, Qena, Egypt \\
\hline
\end{tabular}

* L1 - L7 landraces

unfavorable conditions. Furthermore, to detect and test the level of genetic diversity and the genetic relationships among all these collected landraces

\section{MATERIALS AND METHODS}

\section{Plant Materials and Growth Conditions}

Seven Jew's Mallow (Corchorus olitorius L.) landraces namely, L1, L2, L3, L4, L5, L6 and L7 were collected from different locations of Egypt and were used in the current study (Tab. I). The morphological screening experiment was performed in two summer seasons of 2018 and 2019, at the Agricultural Experimental Farm, Faculty of Agriculture, South Valley University, Qena Governorate, Egypt, the site is at (latitude 26 $16^{\circ} 22.2$ ' $\mathrm{N}$ to Longitude $\left.32^{\circ} 44^{\prime} 25.5^{\prime \prime} \mathrm{E}\right)$, and $81 \mathrm{~m}$ above sea level. Monthly maximum and minimum temperature degree of Qena region, Egypt were listed in Fig. 1.

Seeds of the seven landraces were sown, on $25^{\text {th }}$ and 26 $6^{\text {th }}$ March 2018 and 2019, respectively. The seeds were sown in rows about $20 \mathrm{~cm}$ apart and then irrigated. Plants were thinned to 5 or $20 \mathrm{~cm}$ between plants for fresh leafy yield or seed yield, respectively. Each experimental unit consisted of 10 rows, each of $4 \mathrm{~m}$ in length and $0.20 \mathrm{~m}$ apart, i.e.,

Temperature-Qena, Egypt 2018-2019

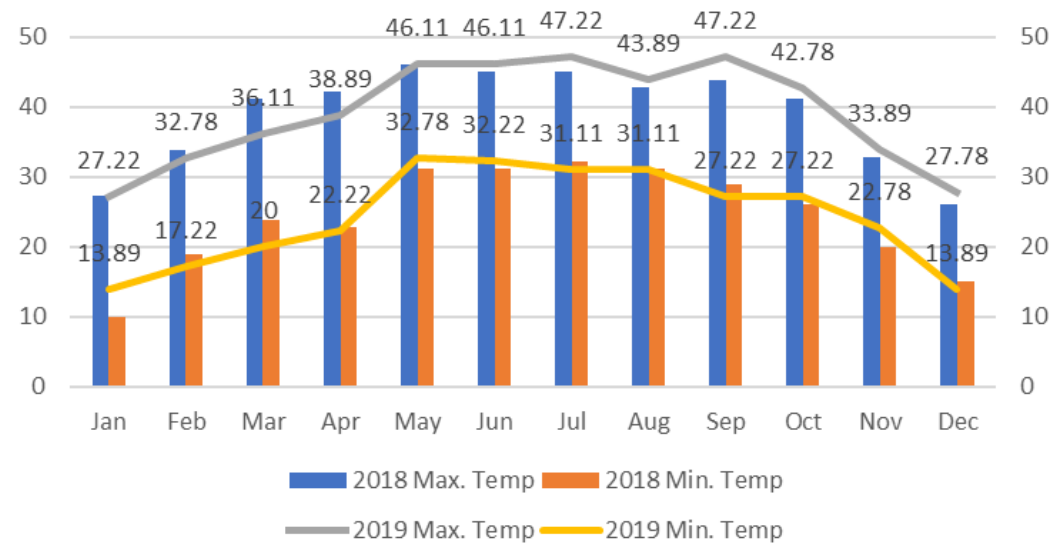

1: Monthly temperature degree maximum and minimum of Qena, Egypt 
the unit area was $8 \mathrm{~m}^{2}$. Three cuttings were taken from each genotype for fresh leafy yield. The first cut was at 40 days after sowing, while the second and the third cuts were taken 25 days intervals. Differential water-stress regimes were imposed at 3 weeks after emergence. The plants were irrigated every 5 days (95\% FC field capacity) as a control, and stress treatment was irrigated every 10 days (60\% FC). The total amounts of applied irrigation throughout both seasons were calculated according to the concept of equivalent water depth. It equaled to $13000 \mathrm{~m}^{3}$ hectare $^{-1}$ for the control (irrigation at $95 \% \mathrm{FC}$ ) and $8300 \mathrm{~m}^{3}$ hectare $^{-1}$ for the stress (irrigation at 60\% FC).The furrows were small, parallel channels, made to carry water to irrigate the plants by surface irrigation.

The furrows are small, parallel channels, made to carry water to irrigate the plants by surface irrigation. The irrigation treatments were separated by five meters to avoid horizontal soil water movement. The recommended that agronomic practices were followed to obtain optimum yield.

\section{Morphological Phenotypic Measurements}

\section{Fresh Foliage Yield and Its Components}

In each cut, vegetative measurements were recorded as a mean of 20 randomly taken plants per entry. These characters were: stem length (SL) (cm), plant weight (PW) (g), leaves weight per plant (LW/P) (g), plant height $(\mathrm{PH})(\mathrm{cm})$, and the number of leaves/ plant (No. L/P). Total fresh foliage yield (TFY) was recorded in Kg per plot as the total weight of plants for each cutting each entry and the total yield in $\mathrm{kg}$ per $\mathrm{m}^{2}$ was calculated for the three cuts taken from each entry.

\section{Seed Yield and Its Components}

At the end each of the season, the following traits were recorded as an average of 20 randomly taken plants; total seed yield/plant (SY/P) (g/plant), number of pods/plant (NP/P), number of seeds/pod (NS/P) and weight of 1000 seeds (W1000 S) (g).

\section{Physiological Traits}

\section{Relative Amount of Chlorophyll Content (RCC)}

The relative amount of chlorophyll content was determined by chlorophyll Meter (Minolta SPAD502 meter, Tokyo, Japan). Fifteen readings per plant (five leaves per plant) were taken from the widest portion of the leaf lamina, to avoid major veins. The samples were selected with concerning the heterogeneities within each sample point. The selected leaves were clean, dry, green and free of signs of disease or damage. Then the values were averaged as SPAD units.

\section{Proline Content Determination (PROC)}

Free proline was determined according to Bates et al. (1973). Samples (100 mg) were homogenized in $10 \mathrm{ml}$ of $3 \%$ aqueous sulfosalicylic acid for $10 \mathrm{~min}$, followed by filtration. Two milliliters of the filtrate were mixed with $2 \mathrm{ml}$ of glacial acetic acid and $2 \mathrm{ml}$ of acid ninhydrin and then warmed in a water bath for $1 \mathrm{~h}$ at $90^{\circ} \mathrm{C}$. After cooling, the developed color was extracted in $4 \mathrm{ml}$ toluene and measured by a photometric method using T80 UV-VIS Spectrophotometer at $520 \mathrm{~nm}$ against toluene. The content of proline was determined from the constructed calibration curve constructed using standard solutions of L-proline at concentrations ranging from 0.01 to $1 \mathrm{mM}$. The level of free proline in control was taken at 100\%.

\section{Drought Indices}

Some drought indices were calculated using the equations according to Fernandez (1992) for stress tolerance index (STI), Fischer and Maurer (1978) for stress susceptibility index (SSI) and Rosielle and Hamblin (1981) for tolerance (TOL) and geometric mean productivity (GMP).

\section{Statistical Analysis}

All obtained data were statistically analyzed with the technique of analysis of variance (ANOVA) by using SAS computer software package SAS 9.1 program software, (SAS, 2004). Also, the Least Significant of Difference (LSD) method was used to test the differences between treatment means at a $5 \%$ level of probability as described by (Gomez and Gomez, 1984).

\section{Molecular Characterization}

The molecular study was done at the Department of Genetics, Faculty of Agriculture, New Valley University, Egypt.

\section{DNA Extraction}

Fresh young leaves were collected from 40 selected randomly seedlings for each genotype. The leaves were ground under liquid nitrogen to a fine powder and then the genomic DNA was extracted using DNA isolation kit (Favorgenv Biotech Corp. Cat. No. FAPGK001) as described in the manufacturer manual. DNA quality and quantity were performed by spectrophotometer, and then were diluted to a final concentration of $50 \mathrm{ng} / \mu \mathrm{L}$.

\section{PCR Analysis}

Twelve RAPD primers were used; they were purchased from EZ Biolab, USA. PCR reactions were performed in $25-\mu \mathrm{L}$ reactions containing $2.5 \mu \mathrm{L}$ of PCR buffer (10X) containing $\mathrm{MgCl}_{2}(15 \mathrm{mM}), 1.5 \mu \mathrm{L}$ of $10 \mathrm{mM}$ dNTPs, $2 \mu \mathrm{Lof} 10 \mu \mathrm{M}$ of each primer, $0.2 \mu \mathrm{L}$ of Taq DNA polymerase ( $5 \mathrm{U} / \mu \mathrm{L})$ and $2 \mu \mathrm{L}$ (50 ng) of genomic DNA. PCR amplifications were performed in a Thermal Cycler (Labocon, U.K.). The instructions of 
the used program as follows: initial denaturation at $94^{\circ} \mathrm{C}$ for $5 \mathrm{~min}$, followed by 35 cycles of denaturation at $94^{\circ} \mathrm{C}$ for $1 \mathrm{~min}$, annealing at $35^{\circ} \mathrm{C}$ for $1 \mathrm{~min}$, and extension at $72^{\circ} \mathrm{C}$ for $3 \mathrm{~min}$ and a final extension at $72{ }^{\circ} \mathrm{C}$ for $7 \mathrm{~min}$. PCR products were separated on $1.5 \%$ agarose gel using 1×TBE (Tris-Borate-EDTA) running buffer at $5 \mathrm{~V} / \mathrm{cm}$ and then, the gels were stained with ethidium bromide $(0.5 \mu \mathrm{g} / \mathrm{ml})$ and visualized under UV light.

\section{Data Analysis}

The detected bands were scored as 1 (present) and 0 (absent). Cluster analysis was carried out using the unweighted pair group method with arithmetical average (UPGMA) and dendrograms were constructed based on Jaccard's genetic similarity index (1908). Statistical analysis was performed using the software MEGA program. Resolving power $(R p)$ of each primer was calculated using the formula: $R p=\sum I_{b}$ (Band informativeness) according to of Jaccard's genetic similarity index (1908). Whereas, $I_{b}$ was calculated by the formula of $I_{b}=1-(2 \times|0.5-p|)$, where $p$ is the percentage of genotypes containing the band. PIC was calculated according to $1-p^{2}-q^{2}$, where $p$ is frequency of present band and $q$ is the frequency of the absent band.

\section{RESULTS AND DISCUSSION}

\section{Performance of Jew's Mallow Landraces}

\section{Vegetative Growth Evaluation}

According to the analysis of variance, results in Tab. II shows significant differences among soil moisture stress conditions, the landraces and their interactions for all the measured traits. Concerning the TFY, under the favorable condition, its value ranged from 5.97 to $8.37 \mathrm{~kg}$ for L1 and L6, respectively. In contrast, these values were reduced under the stress condition and ranged from 3.60 to $6.95 \mathrm{~kg}$ for also L1 and L6, respectively Tab. II. Clearly that the L1 was the most sensitive to drought stress and it had a reduction of 39.7\%, while L6 was the most tolerant landrace and had

II: Means performance and mean squares of growth traits of $7 \mathrm{Jew}$ 's Mallow landraces under water deficit, calculated from the combined data over two seasons, 2018 and 2019

\begin{tabular}{|c|c|c|c|c|c|c|c|}
\hline Landraces & FC \% & TFY (Kg) & PW (g) & $\mathrm{LW} / \mathrm{P}(\mathrm{g})$ & $\mathrm{PH}(\mathrm{cm})$ & No. L/P & SL (cm) \\
\hline \multirow{2}{*}{ L1 } & FC 95 & $5.97 \mathrm{fg}$ & $33.35 \mathrm{e}$ & $12.34 \mathrm{~d}$ & $57.83 \mathrm{a}$ & $14.00 \mathrm{~d}$ & $43.34 \mathrm{e}$ \\
\hline & FC 60 & $3.60 \mathrm{j}$ & $20.00 \mathrm{k}$ & $7.55 \mathrm{~h}$ & $35.47 \mathrm{~h}$ & $8.95 \mathrm{k}$ & $25.74 \mathrm{j}$ \\
\hline \multirow{2}{*}{ L2 } & FC 95 & $6.54 \mathrm{de}$ & $27.38 \mathrm{i}$ & $17.30 \mathrm{a}$ & $44.20 \mathrm{e}$ & $12.52 \mathrm{f}$ & $23.56 \mathrm{k}$ \\
\hline & FC 60 & $4.32 \mathrm{i}$ & $20.05 \mathrm{k}$ & $11.33 \mathrm{e}$ & $29.16 j$ & 8.001 & $15.97 \mathrm{~m}$ \\
\hline \multirow{2}{*}{ L3 } & FC 95 & $6.02 \mathrm{fg}$ & $30.04 \mathrm{~h}$ & $17.03 \mathrm{a}$ & $33.81 \mathrm{i}$ & $14.53 \mathrm{c}$ & $27.11 \mathrm{i}$ \\
\hline & FC 60 & $4.19 \mathrm{i}$ & $20.10 \mathrm{k}$ & $11.25 \mathrm{e}$ & $22.50 \mathrm{k}$ & $9.10 \mathrm{jk}$ & 19.221 \\
\hline \multirow{2}{*}{ L4 } & FC 95 & $7.81 \mathrm{~b}$ & $41.08 \mathrm{c}$ & $12.53 d$ & $39.88 \mathrm{~g}$ & $12.00 \mathrm{~h}$ & $47.67 \mathrm{~d}$ \\
\hline & FC 60 & 6.25 ef & $32.00 \mathrm{f}$ & $10.08 \mathrm{f}$ & $34.67 \mathrm{hi}$ & $9.27 \mathrm{j}$ & $38.17 \mathrm{~g}$ \\
\hline \multirow{2}{*}{ L5 } & FC 95 & $6.58 \mathrm{~d}$ & $49.96 \mathrm{~b}$ & $11.43 \mathrm{e}$ & $52.33 \mathrm{c}$ & $15.00 \mathrm{~b}$ & $39.51 \mathrm{f}$ \\
\hline & FC 60 & $5.00 \mathrm{~h}$ & $37.00 \mathrm{~d}$ & $8.59 \mathrm{~g}$ & $40.00 \mathrm{~g}$ & $11.05 \mathrm{i}$ & $29.58 \mathrm{~h}$ \\
\hline \multirow{2}{*}{ L6 } & FC 95 & $8.37 \mathrm{a}$ & $67.99 \mathrm{a}$ & $14.45 \mathrm{c}$ & $48.79 \mathrm{~d}$ & $14.96 \mathrm{~b}$ & $60.36 \mathrm{a}$ \\
\hline & FC 60 & $6.95 \mathrm{c}$ & $57.00 \mathrm{~b}$ & $12.61 \mathrm{~d}$ & $42.90 \mathrm{f}$ & $12.25 \mathrm{~g}$ & $54.51 \mathrm{c}$ \\
\hline \multirow{2}{*}{ L7 } & FC 95 & $7.62 \mathrm{~b}$ & $31.06 \mathrm{~g}$ & $15.98 \mathrm{~b}$ & $54.54 \mathrm{~b}$ & $17.96 \mathrm{a}$ & $55.41 \mathrm{~b}$ \\
\hline & FC 60 & $5.85 \mathrm{~g}$ & $24.08 \mathrm{j}$ & $12.53 \mathrm{~d}$ & $42.55 \mathrm{f}$ & $13.00 \mathrm{e}$ & $43.68 \mathrm{e}$ \\
\hline LSD 05 & & 0.2963 & 0.2095 & 0.4512 & 1.052 & 0.2364 & 0.4377 \\
\hline \multicolumn{8}{|c|}{ Mean Squares } \\
\hline SOV & d.f & & & & & & \\
\hline Landraces & 6 & $6.950^{* *}$ & $1022.350^{* *}$ & $24.315^{* *}$ & $335.854^{* *}$ & $20.211^{* *}$ & $1109.287^{* *}$ \\
\hline Field Capacity & 1 & $34.90^{* *}$ & $1392.992^{* *}$ & $157.517^{* *}$ & $1517.164^{* *}$ & $184.716^{* *}$ & $1053.109^{* *}$ \\
\hline $\mathrm{L} \times \mathrm{FC}$ & 6 & $0.189^{* *}$ & $18.760^{* *}$ & $4.080^{* *}$ & $50.183^{* *}$ & $1.838^{* *}$ & $22.109^{* *}$ \\
\hline Error & 28 & 0.0222 & 0.0105 & 0.051 & 0.277 & 0.0145 & 0.0477 \\
\hline
\end{tabular}

The different letters represent statistically significant differences between treatments $(p<0.05)$.

*FC (Field Capacity), (TFY) total fresh foliage yield, (PW) plant weight, (LW/P) leaves weight, (PH) plant height, (No. L/P) the number of leaves/plant, and (SL) stem length. 
a reduction of $17.0 \%$. Moreover, the plant weights of all the landraces were significantly affected by soil moisture stress Tab. II. L6 produced the heaviest plants under both normal and stress conditions (67.99 and $57 \mathrm{~g}$ ), respectively. on the contrary, L1 gave the lowest value (20.0 g) of the plant weights under stress conditions. For leaves weight per plant trait, all the landraces were significantly affected by soil moisture stress conditions. The most reduction of leaves weight was observed by L1 (38.8\%), but L6 had the highest value (12.61 g) of leaves weight under the stress condition. Furthermore, the plant height significantly varied among all the landraces under both the normal and stressed conditions, L1 had the most reduction. All the landraces were significantly affected by the stress conditions, the best tolerant landrace observed was L6 with reduction $(5.9 \mathrm{~cm}, 12.1 \%)$. On the other hand, the leaves number per plant ranged from 17.96 l/p for the L7 to 12.0 for the L4 under normal conditions. Soil moisture stress decreased the number of leaves per plant for all landraces, the L7, L6 and L5 showed the highest value (13.0, 12.3 and 11.1, respectively), while the lowest number was given by the L2 and L1. Moreover, L1 and L2 had the highest reduction value (36.1\%). Furthermore, the stem length trait was measured and L1 recorded the most reduction (40\%) in both favorable and unfavorable conditions. As well, L6 had the highest value (60.36 and 54.51) under both favorable and unfavorable conditions, respectively. The obtained results indicated the growth of $C$. olitorius landraces were significantly affected by soil moisture stress, for all studied traits. The results are in harmony with findings by (Fawusi, et al. 1984; Ayodele and Fawusi, 1989 and 1990; Prodhan et al., 2001; Shiwachi et al., 2008; Fasinmirin and Olufayo, 2009; Ghosh et al., 2013 and Dhar et al., 2018). They reported that C. olitorius plants which grown under drought stress were found to be shorter than plants that received full irrigation. Also, they found that the stem length, total fresh foliage yield, plant weight, leaves weight and number of leaves per plant were decreased significantly under water deficit conditions. These results may be due to that $C$. olitorius landraces responded diversely to different environments, suggesting the screening of cultivars under different environments are viewed as the most effective method for obtaining tolerant genotypes (El-Shaieny, 2017). In addition to, inhibition of cell division or cell enlargement and plant wilting grown under stress conditions (Raza et al., 2014; Khan et al., 2015; El-Shaieny, 2017; Yakoub et al., 2016) study the effects of different water supply treatments (100\%, 70\% and $40 \%$ of the field water capacity) on agronomic and physiological parameters of $C$. olitorius plants, they reported that significant differences were obtained at $\mathrm{P}<0.05$, in all studied characters under acute and severe soil moisture stress as compared with control treatment.

\section{Seed Yield and Its Components}

Seed yield and its attributes were significantly affected by soil moisture stress in all the landraces Tab. III. L1 was the most susceptible to soil moisture stress that had the lowest seed yield value (3.96 g), but L6 was the best one that produced the highest value of seed yield $(5.72 \mathrm{~g})$. On the other hand, L6 had the best performance of the number of pods per plant (60.33 and 54.33) under both unstressed and stressed conditions, respectively. In contrast, L1 and L2 recorded the most reduction (37.9\% and $32.6 \%$ ), respectively. For the number of seeds per pod, L1 landrace showed the highest reduction (31.6\%), while the lowest reduction was 9.9\% in L6. About the weight of 1000 seeds per plant, the values ranged from $1.21 \mathrm{~g}$ to $1.91 \mathrm{~g}$ for L2 and L1, respectively. Moreover, W1000S was significantly affected by soil moisture stress, the highest reduction value (11.3\%) was recorded by L1, while the L5, L2 and L6 landraces had the lowest reduction values (0.6, 0.8 and 1.0\%), respectively. The seeds yield per plant traits were reduced significantly for all studied traits under unfavorable condition (60\% FC). These results indicate that water deficit decreased vegetative growth parameters, due to its harmful role in the photosynthesis processes, this led to a decrease in growth and development of plants, as a result of energy impairment production in the plant cell. Similar results were detected in tomatoes (Pervez et al., 2009; Celebi, 2014; Khan et al., 2015) cowpea (Farouk et al., 2011; Hussein et al., 2014; Hussein and Abd El-Hady, 2015; El-Shaieny, 2017) and wheat (Al Ameen, 2012; Kheiralla and Ismail, 1995).

\section{Physiological Traits}

\section{Relative Amount of Chlorophyll and Proline Contents}

For further screening of drought-tolerant landraces, we measured the relative amount of chlorophyll and proline under a normal and stressed condition. Concerning the relative amount of chlorophyll content, the results in Tab. III showed that the highest value (84.86) was detected in L2 at normal condition, but at abnormal conditions, both L2 and L6 shared the highest value. For proline content, water deficit stress caused a significant increase in proline amount in all landraces. The highest accumulation of proline was 4.29 in L6 Tab. III. Clearly, the relative amount of chlorophyll content decreased with the increasing drought stress levels. While severe and moderate water deficit increased proline content in the leaves, that may be due to the ability of plants to maintain normal physiological functions and to adapt to unfavorable environments. 
III: Means performance and mean squares of yield components and chlorophyll and proline content of $7 \mathrm{Jew}$ 's Mallow landraces under water deficit, calculated from the combined data over two seasons, 2018 and 2019

\begin{tabular}{|c|c|c|c|c|c|c|c|}
\hline Landraces & FC $\%$ & SY/P (g) & No. $\mathrm{P} / \mathrm{P}$ & $\mathrm{NS} / \mathrm{P}$ & W1000S (g) & RCC & PROC \\
\hline \multirow{2}{*}{ L1 } & FC 95 & $5.33 \mathrm{~d}$ & $45.08 \mathrm{e}$ & $192.43 \mathrm{~b}$ & $1.60 \mathrm{i}$ & $78.48 \mathrm{~b}$ & $2.55 d$ \\
\hline & FC 60 & $3.96 \mathrm{~g}$ & $28.00 \mathrm{~h}$ & $131.67 \mathrm{k}$ & $1.42 \mathrm{j}$ & $59.46 \mathrm{j}$ & $4.16 \mathrm{a}$ \\
\hline \multirow{2}{*}{ L2 } & FC 95 & $6.44 \mathrm{~b}$ & $35.33 \mathrm{~g}$ & $137.67 \mathrm{j}$ & $1.21 \mathrm{~m}$ & $84.86 \mathrm{a}$ & $2.16 \mathrm{e}$ \\
\hline & FC 60 & $4.50 \mathrm{f}$ & $23.83 \mathrm{i}$ & $100.33 \mathrm{~m}$ & $1.20 \mathrm{n}$ & $72.63 \mathrm{f}$ & $4.19 \mathrm{a}$ \\
\hline \multirow{2}{*}{ L3 } & FC 95 & $6.20 \mathrm{~b}$ & $35.00 \mathrm{~g}$ & 179.67 e & $1.78 \mathrm{c}$ & $75.71 \mathrm{~d}$ & $2.17 \mathrm{e}$ \\
\hline & FC 60 & $4.57 \mathrm{f}$ & $24.00 \mathrm{i}$ & 124.671 & $1.76 \mathrm{~d}$ & $60.88 \mathrm{i}$ & $3.93 \mathrm{~b}$ \\
\hline \multirow{2}{*}{ L4 } & FC 95 & $6.43 \mathrm{~b}$ & $55.33 \mathrm{~b}$ & $174.67 \mathrm{f}$ & $1.63 \mathrm{~g}$ & $71.61 \mathrm{fg}$ & $1.94 \mathrm{f}$ \\
\hline & FC 60 & $4.52 \mathrm{f}$ & $49.33 \mathrm{~d}$ & $140.33 \mathrm{i}$ & $1.61 \mathrm{~h}$ & 61.33 i & $3.79 \mathrm{bc}$ \\
\hline \multirow{2}{*}{ L5 } & FC 95 & $6.36 \mathrm{~b}$ & $54.67 \mathrm{bc}$ & $196.67 \mathrm{a}$ & $1.70 \mathrm{e}$ & $73.84 \mathrm{e}$ & $1.90 \mathrm{f}$ \\
\hline & FC 60 & $4.98 \mathrm{e}$ & $45.00 \mathrm{e}$ & 139.00ij & $1.69 \mathrm{f}$ & $60.87 \mathrm{i}$ & $3.70 \mathrm{c}$ \\
\hline \multirow{2}{*}{ L6 } & FC 95 & $6.98 \mathrm{a}$ & 60.33 a & 189.33 c & $1.91 \mathrm{a}$ & $71.35 \mathrm{~g}$ & $1.37 \mathrm{~g}$ \\
\hline & FC 60 & $5.72 \mathrm{c}$ & 54.33 c & $170.67 \mathrm{~g}$ & $1.89 \mathrm{~b}$ & $65.42 \mathrm{~h}$ & $4.29 \mathrm{a}$ \\
\hline \multirow{2}{*}{ L7 } & FC 95 & $5.80 \mathrm{c}$ & $40.33 \mathrm{f}$ & $184.67 d$ & $1.41 \mathrm{k}$ & $77.09 \mathrm{c}$ & $1.87 \mathrm{f}$ \\
\hline & FC 60 & $4.65 \mathrm{f}$ & $34.67 \mathrm{~g}$ & $151.65 \mathrm{~h}$ & 1.391 & $65.22 \mathrm{~h}$ & $3.65 \mathrm{c}$ \\
\hline LSD 05 & & 0.3222 & 0.8890 & 2.666 & 0.004467 & 1.076 & 0.1998 \\
\hline \multicolumn{8}{|c|}{ Mean Squares } \\
\hline SOV & d.f & & & & & & \\
\hline Landraces & 6 & $1.230^{* *}$ & $763.447^{* *}$ & $2255.625^{* *}$ & $0.332^{* *}$ & $103.840^{* *}$ & $0.300^{* *}$ \\
\hline Field Capacity & 1 & $24.335^{* *}$ & $959.537^{* *}$ & $18873.936^{* *}$ & $0.0168^{* *}$ & $1626.406^{* *}$ & $40.535^{* *}$ \\
\hline $\mathrm{E} \times \mathrm{FC}$ & 6 & $0.475^{* *}$ & $25.739^{* *}$ & $367.780^{* *}$ & $0.0058^{* *}$ & $24.172^{* *}$ & $0.290^{* *}$ \\
\hline Error & 28 & 0.0257 & 0.198 & 1.781 & 0.00003 & 0.291 & 0.00978 \\
\hline
\end{tabular}

The different letters represent statistically significant differences between treatments $(p<0.05)$.

*Field capacity (FC), (SY/P) seed yield per plant, (No. P/P) number of pod per plant, (NS/P) number of seeds per pod, (W1000S) weight of 1000 seeds, (RCC) relative amount of chlorophyll content, and (PROC) proline content.

\section{Drought Tolerance Parameters}

Furthermore, to identify the most drought stress tolerant landraces, some drought tolerance indices were calculated based on their grain yield under non-stress and stress conditions Tab. IV. L4 and L6 were the most tolerant genotypes, they had the highest value of stress tolerance index (STI) (1.00 and 1.09) and geometric mean productivity (GM) (6.99 and 7.63), respectively. Furthermore, they had the least values of stress susceptibility index (SSI) (0.768 and 0.653), respectively. Landraces with low SSI values $(<1)$ can be considered to be drought-tolerant, due to the exhibited smaller yield reductions under water stress compared with well-watered conditions than the mean yield of all landraces. SSI and STI could able to differentiate the tolerant genotypes under drought stress conditions, which are fitted with many previous studies (Andarab, 2013; Anwaar et al., 2020; SánchezReinoso et al., 2020).

\section{Molecular Analysis}

\section{C-RAPD Marker Analysis}

To study genetic diversity and relationship among the studied seven genotypes, RAPD molecular marker was performed. Twelve primers were used Fig. 2 and they detected 140 bands with size varied from 135 to $2440 \mathrm{bp}$. Only 82 bands out of them were polymorphic, with a range of 20 to $84.62 \%$ polymorphism Tab. V. The lowest polymorphism was given by OPG14, while S12 primer gave the highest polymorphism (84.62). Furthermore, the polymorphism average was $58.6 \%$. Indeed, this moderate level of polymorphism indicating the presence of moderate variability among evaluated landraces. Many researchers have been used RAPD markers to assess the genetic diversity in Jew's Mallow. In the current study, the detected polymorphism rate was slightly higher than the finding of Heikal et al. (2015), (28.3\%) and Youssef et al. (2019) (44.44\%). Moreover, the estimated OPC12 value ranged from 0.07 to 0.33 with an average of 0.21 . The lowest value was 


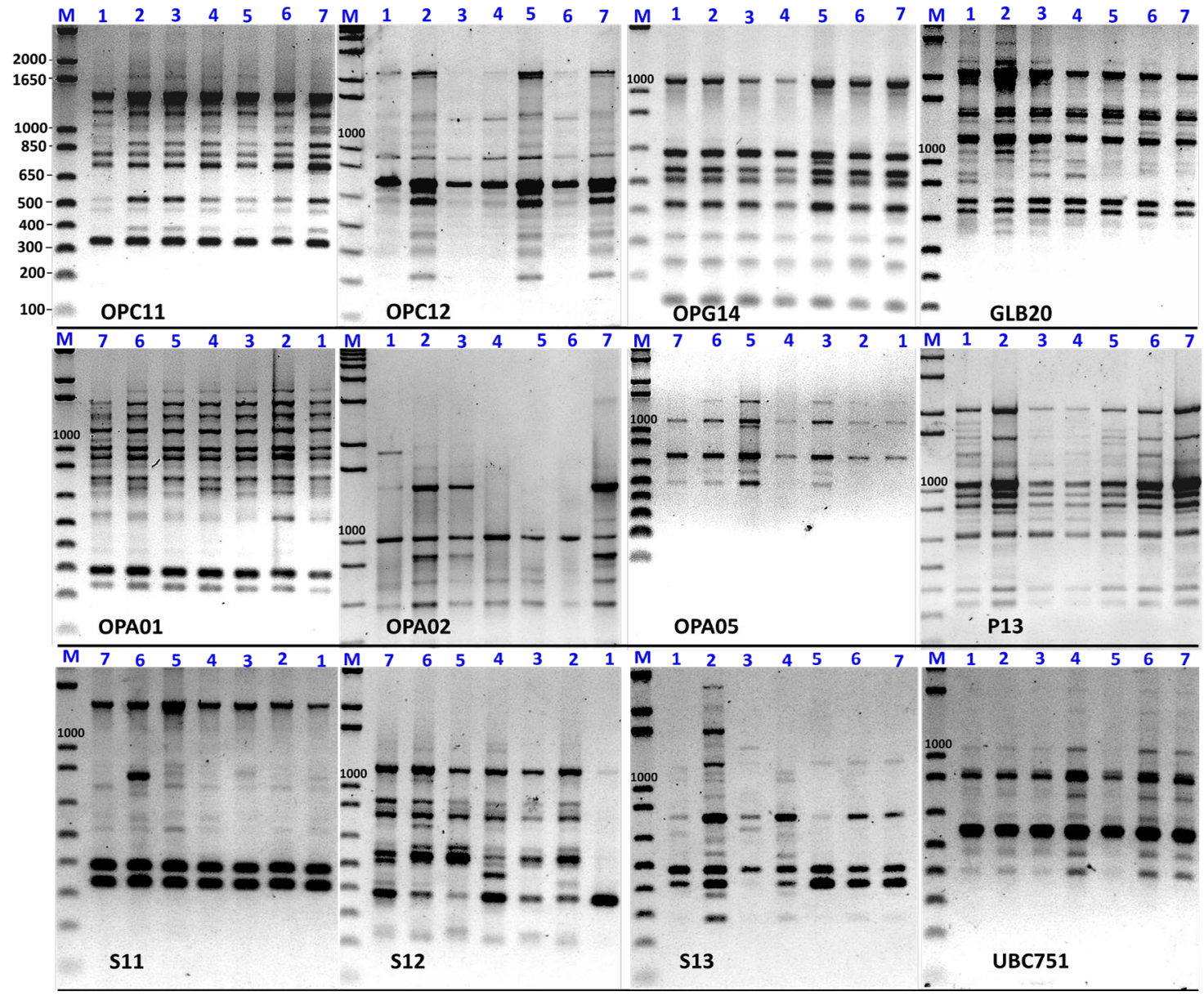

2: RAPD pattern of 7 Jew's Mallow landraces was produced by twelve primers. 1, L1; 2, L2; 3, L3; 4, L4; 5, L5; 6, L6; 7, L7. M, kbp DNA marker.

IV: Mean comparison between Jew's Mallow landraces for total fresh foliage yield ( $\mathrm{kg}$ ), under favorable and unfavorable conditions

\begin{tabular}{lcccccccl}
\hline \multicolumn{1}{c}{ Landraces } & $\mathrm{Y}_{\mathrm{p}}$ & $\mathrm{Y}_{\mathrm{S}}$ & STI & SSI & TOL & GM & RDY & \multicolumn{1}{c}{ Class } \\
\hline L1 & 5.97 & 3.60 & 0.66 & 1.527 & 2.37 & 4.64 & 0.397 & More sensitive \\
L2 & 6.54 & 4.32 & 0.76 & 1.306 & 2.22 & 5.32 & 0.339 & Moderate sensitive \\
L3 & 6.02 & 4.19 & 0.72 & 1.169 & 1.83 & 5.02 & 0.304 & Moderate sensitive \\
L4 & 7.81 & 6.25 & 1.00 & 0.768 & 1.56 & 6.99 & 0.200 & High Tolerant \\
L5 & 6.58 & 5.00 & 0.82 & 0.924 & 1.58 & 5.74 & 0.240 & Moderate Tolerant \\
L6 & 8.37 & 6.95 & 1.09 & 0.653 & 1.42 & 7.63 & 0.170 & High Tolerant \\
L7 & 7.62 & 5.85 & 1.09 & 0.893 & 1.77 & 6.68 & 0.232 & Moderate Tolerant \\
Mean & 6.99 & 5.17 & & & & & & \\
\hline
\end{tabular}

(STI) Stress tolerance index, (SSI) stress susceptibility index, (TOL) tolerance index, (GMP) geometric mean productivity, (RDY) yield reduction

for the OPG14 primer, but the highest value was recorded by the OPC12 primer. Furthermore, the estimated Rp value ranged from 0.86 for OPG14 primer to 6.58 for the OPC12 primer. However, the OPC12 primer had the highest value for both PIC and $\mathrm{Rp} \%$ that makes it the most informative used primer. On the other hand, the cluster analysis of genetic similarity matrices, according to Jaccard's similarity coefficient Tab. VI revealed that, high similarity (0.61 to 0.84) was detected among all the seven genotypes. The highest similarity (0.84) was between L4 and L6 landraces, while L1 and L7 showed the lowest similarity (0.61). Moreover, the constructed dendrogram by UPGMA classified the seven landraces into two main clusters Fig. 3. The first one contained only the L1 landrace, while the 
V: Polymorphism obtained by twelve RAPD primers in 7 Jew's Mallow landraces

\begin{tabular}{|c|c|c|c|c|c|c|c|c|}
\hline Primers & $\begin{array}{l}\text { Primer sequence } \\
5^{\prime} \rightarrow 3^{`}\end{array}$ & $\begin{array}{l}\text { Range } \\
\text { of fragment } \\
\text { size bp }\end{array}$ & $\begin{array}{l}\text { Total No. } \\
\text { of fragments }\end{array}$ & $\begin{array}{l}\text { Monomorphic } \\
\text { fragments }\end{array}$ & $\begin{array}{l}\text { Polymorphic } \\
\text { fragments }\end{array}$ & $\begin{array}{c}\text { Polymorphism } \\
\%\end{array}$ & PIC & $\mathrm{RP}$ \\
\hline OPC11 & AAAGCTGCGG & 330-1380 & 13 & 9 & 4 & 30.77 & 0.09 & 1.42 \\
\hline OPC12 & TGTCATCCCC & 135-1125 & 12 & 3 & 9 & 75 & 0.33 & 6.58 \\
\hline OPG14 & GGATGAGACC & 135-1083 & 10 & 8 & 2 & 20 & 0.07 & 0.86 \\
\hline GLB20 & GCACССTTAC & $690-2440$ & 14 & 8 & 6 & 42.86 & 0.16 & 3.42 \\
\hline OPA01 & CAGGCCCTTC & 210-1760 & 13 & 10 & 3 & 23.08 & 0.08 & 1.44 \\
\hline OPA02 & TGCCGAGCTG & 645-1885 & 9 & 2 & 7 & 77.78 & 0.27 & 3.7 \\
\hline OPA05 & AGGGGTCTTG & 475-1455 & 6 & 2 & 4 & 66.67 & 0.25 & 2.02 \\
\hline P13 & GGAGTGCCTC & 400-2070 & 15 & 4 & 11 & 73.33 & 0.25 & 5.42 \\
\hline S11 & GTA GAC CCGT & $320-1400$ & 10 & 4 & 6 & 60 & 0.19 & 2.84 \\
\hline S12 & CCT TGA CGCA & $185-1120$ & 13 & 2 & 11 & 84.62 & 0.29 & 5.7 \\
\hline S13 & TTC CCC CGCT & 280-1640 & 16 & 3 & 13 & 81.25 & 0.26 & 5.72 \\
\hline UBC751 & CCC ACC ACA C & 395-1046 & 9 & 3 & 6 & 66.67 & 0.23 & 3.14 \\
\hline Mean & & & 11.67 & 4.83 & 6.83 & 58.50 & 0.21 & 3.52 \\
\hline Total & & & 140 & 58 & 82 & & & \\
\hline
\end{tabular}

VI: The similarity indices among the 7 Jew's Mallow landraces based on RAPD marker

\begin{tabular}{lccccccc}
\hline Landraces & L1 & L2 & L3 & L4 & L5 & L6 & L7 \\
\hline L1 & 1.00 & & & & & & \\
L2 & 0.64 & 1.00 & & & & & \\
L3 & 0.71 & 0.71 & 1.00 & & & & \\
L4 & 0.66 & 0.68 & 0.69 & 1.00 & & & \\
L5 & 0.64 & 0.68 & 0.70 & 0.67 & 1.00 & & \\
L6 & 0.66 & 0.68 & 0.72 & 0.84 & 0.72 & 1.00 & 1.00 \\
\hline L7 & 0.61 & 0.74 & 0.72 & 0.72 & 0.76 & 0.77 & \\
\hline
\end{tabular}

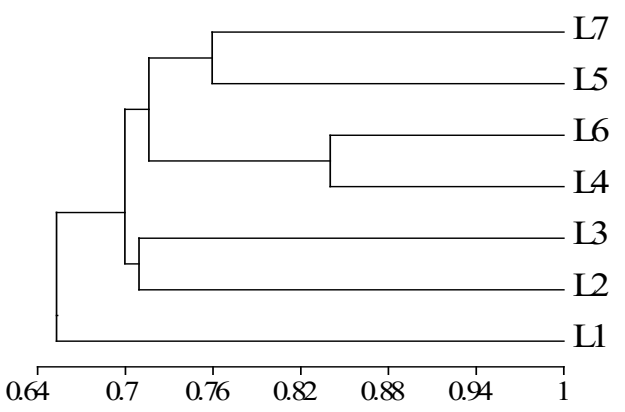

3: The dendrogram of genetic distances among the 7 Jew's Mallow landraces using UPGMA cluster analysis of Jaccard's similarity coefficient based on RAPD marker second one contained all the collected landraces from Upper Egypt and divided into two sub-clusters, one of them contained L2 and L3 landraces, but the second one divided into two groups, one of them gathered both L4 and L6 landraces, but the second one contained L5 and L7. The constructed dendrogram could able to separate the landraces according to their geographic location, whereas the landraces which were collected from Alexandria were located in one cluster, and the rest of landraces were collected from Upper Egypt grouped in the other cluster. Classifications of these landraces are consistent with the results of Heikal et al. (2015). The Upper Egypt landraces are genetically close similar, this may be because they evolved from the same ancestral origin. 


\section{CONCLUSION}

Landraces are a reliable source for the detection of genetic variability. Thus, the present study aimed to evaluate seven landraces that were collected from different locations across Egypt. They were evaluated according to their morphology and molecular diversity under drought stress. All the studied traits significantly varied among all the evaluated landraces whether under normal or stressful conditions. Among them, both landraces L6 and L4 revealed superior performance under soil moisture stress. On the other hand, the RAPD marker had a powerful ability to distinguish the genetic diversity among the collected landraces. The similarity among them was high. Furthermore, the dendrogram was able to classify all the landraces according to their geographic region and their drought tolerance ability. However, the superiority of the L7 landrace under drought stress suggested that landraces could be used through the genetic improvement breeding program of Jew's Mallow.

Acknowledgements

The authors declare that the current research did not receive any specific funding.

\section{REFERENCES}

ABD-ALLAH, S. A. M. 2006. Variation and interrelationships of some Egyptian moloukhyia genotypes (Corchorusolitorius L.). J. Agric. Sci. Mansoura Univ., 31(4): 2285-2296.

ABD-ALLAH, S. A. M. and NASR, M. A. 2006. Effect of sowing date and preservation methods on some Egyptian moloukhyia genotypes (Corchorusolitorius L.). Minufiya J. Agric. Res., 31(4): 981-995.

ABD-ALLAH, S. A. M., HEGAZI, A. Z. and. TOLBA, M. H. 2010. Effect of different plant locations and sowing dates on some Jew's Mallow ecotypes (Corchorusolitorius L.). Nature and Science, 8(9): 270283.

EL-SHAIENY, ABDEL-HALEEM A. H.. 2017a. Drought tolerance of some cowpea genotypes under Upper Egypt conditions. Afr. J. Agric. Res., 12(23): 1993-2001.

EL-SHAIENY, ABDEL-HALEEM A. H. 2017b. Mass selection for enhancement fruit yield in Edkawy cultivar of tomato under different irrigation intervals in southern of Egypt. Nat. Sci., 15(5): 22-29.

ABOU HADID, A. F., EI-SHIILAWY, I. Z., EL BELTAGY, A. S., GAAFER, S. A. and MEDANY, M. A. 1994. Studies on the production of off-season Jew's Mallow "Melokhia" in Egypt. Egypt. J. Hort., 21(2): 187-193.

AHMED, V. U., ALI, A., ALI, Z., BAQAI, F. T. and ZAFAR, F. N. 1998. Cycloartane triterpene glucoside from Corchorus depressus. Phytochemistry, 49(3): 829-834.

AL-AMEEN, T. 2012. Stability analysis of selected wheat genotypes under different environment conditions in Upper Egypt. African. J. of Agric. Research, 34: 4838-4844.

ANDARAB, S. S. 2013. Investigation of drought tolerance using tolerance indexes to identify sensitive and tolerant genotypes in wheat genotypes. Annals of Biological Research, 4(5): 290-294.

ANWAAR, H. A., PERVEEN, R., MANSHA, M. Z., ABID, M., SARWAR, Z. M., AATIF, H. M. and RIZWAN, M. 2020. Assessment of grain yield indices in response to drought stress in wheat (Triticum aestivum L.). Saudi Journal of Biological Sciences, 27(7): 1818-1823.

AYODELE, V. I. and FAWUSI, M. O. A. 1989. Studies on drought susceptibility of Corchorusolitorius L.: I. Effects of stressing plant at mid vegetative stage on dry matter yield and yield components of two cultivars of C. olitorius. Biotronics, 18: 23-27.

AYODELE, V. I. and FAWUSI, M. O. A. 1990. Studies on Drought Susceptibility of Corchorus olitorius L. II. Effects of Moisture Stress at Different Physiological Stages on Vegetative Growth and Seeds Yield of C. olitorius cv. 'Oniyaya'. Biotronics, 19: 33-37.

BASHANDY, T. and EL-SHAIENY, ABDEL-HALEEM A. H. 2016. Screening of Cowpea (Vigna unguiculata L. Walp) genotypes for salinity tolerance using field evaluation and molecular analysis. Journal of Agricultural Chemistry and Biotechnology, 7(9): 249-255.

BATES, L. S., WALDREN, R. P. and TEARE, I. D. 1973. Rapid determination of free proline for waterstress studies. Plant Soil, 39: 205-207.

BOAMAH, P. O., OWUSU-SEKYERE, J. D., SAM AMOAH, L. K. and ANDERSON, B. 2011. Effects of irrigation interval on chlorophyll fluorescence of tomatoes under sprinkler. Asian J. Agric. Res., 5(1): 83-89.

BRUCKNER, P. L. and FROHBERG, R. C. 1987. Stress tolerance and adaptation in spring wheat 1. Crop Sci., 27(1): 31-36.

CELEBI, M. 2014. the effect of water stress on tomato under different emitter discharges and semiarid climate condition. Bulg. J. Agric. Sci., 20: 1151-1157.

FAO. 2018. Jute Production Statistic. Food and Agriculture Organization of the United Nations. 
FAROUK, S. and AMANY R. ABD EL MOHSEN. 2011. Improving growth and yield of cowpea plant by foliar application of chitosan under water stress. J. Plant Production, Mansoura Univ., 2(10): 13411358.

FASINMIRIN, J. T. and OLUFAYO, A. A. 2009. Yield and water use efficiency of jute Mallow Corchorus olitorius under varying soil water management strategies. J. Med. Plants Res., 3: 186-191.

FAWUSI, M. O. A., ORMROD, D. and EASTHAM, P. A. M. 1984. Response to water stress of Celosia argentea and Corchorus olitorius in controlled environments. Scientia Horticulturae, 22: 163-171.

FERNANDEZ, G. C. 1992. Effective selection criteria for assessing plant stress tolerance. In: Proceeding of the International Symposium on Adaptation of Vegetables and other Food Crops in Temperature and Water Stress. Aug. 13-16, Shanhua, Taiwan, pp. 257-270.

FISCHER, R. A. and MAURER, R. 1978. Drought resistance in spring wheat cultivars. 1. Grain yields responses. Australian J. Agric. Res., 29: 897-912.

GHISLAIN, M., ZHANG, D., FAJARDO, D., HUAMANN, Z., HIJMANS, R. H. 1999. Marker-assisted sampling of the cultivated Andean potato Solanum phureja collections using RAPD markers. Genetic Resources and Crop Evolution, 46: 547-555.

GHONEIM, I. M. and EL-ARABY, S. M. 2003. Effect of organic manure source and biofertilizer type on growth, productivity and chemical composition of Jew's Mallow (Corchorus olitorious l.) plants. J. Agric. \& Env. Sci. Alex. Univ., Egypt., 2(2): 88-105.

GHOSH, R. K., PHUMICHAI, T., SREEWONGCHAI, T., NAKASATHIEN, S. and PHUMICHAI, C. 2013. Evaluation of salt tolerance of jute (Corchorus spp.) genotypes in hydroponics using physiological parameters. Asian J. Plant. Sci., 12: 149-158.

GOMEZ, K. A. and GOMEZ, A. A. 1984. Statistical procedures for agricultural research. $2^{\text {nd }}$ Edition. New York: Wiley and Sons.

HAQUE, S., BEGUM, S., SARKER, R. H. and KHAN, H. 2007. Determining genetic diversity of some jute varieties and accessions using RAPD markers. Plant Tissue Culture and Biotechnology, 17(2): 183191.

HEIKAL, H. A., EL-AZEEM, R. M. A. and EL-WAKIL, H. E. 2015. Molecular fingerprinting and phylogenetic relationships among three Egyptian moulokhyia genotypes (Corchorus olitorius L.) using RAPD, ISSR and SRAP markers. Indian Streams Research Journal, 5: 1-12.

HELALY, A. A., ALKHARPOTLY, A. A., MADY, E. and CRAKER, L. E. 2016. Characterization of four Molokhia (Corchorus olitorius) Landraces by Morphology and Chemistry. Journal of Medicinally Active Plants, 5(2): 1-6.

HUSSEIN, A. H. and ABD EL-HADY, M. A. H. 2015. A comparing of some promising lines and commercial cultivars of cowpea. Egypt. J. Plant Breed, 19(1): 101-139.

HUSSEIN, M., AL-ASHRY, M., CAMILIA, S. M., EL DEWINY, Y. 2014. Cowpea growth and yield components as affected by drought and PK soil fertilization. International Journal of Science and Research, 3(12): 2200-2207.

JACCARD, P. 1908. Nouvelles recherches sur la distribution florale. Bull. Soc. Vaud. Sci. Nat., 44: 223270.

JARVIS, D., STHAPIT, B. and SEARS, L. 2000. Conserving Agricultural Biodiversity in Situ: A Scientific Basis for Sustainable Agriculture. Rome, Italy: International Plant Genetic Resources Institute.

KHAN, S. H., KHAN, A., LITAF, U., SHAH, A. S. S., KHAN, M. A., BILAL, M. and ALI, M. U. 2015. Effect of drought stress on tomato cv. Bombino. J. Food Process Technol., 6: 465.

KHEIRALLA, K. A., ISMAIL, A. A. and EL-NAGAR, G. R. 1997. Drought tolerance and stability of some spring wheat cultivars. Assiut J. of Agric. Sci., 28(1): 75-88.

KUMAR, A., SENGAR, R. S., RAO, V. P., SHUKLA, G., DIXIT, R. and SINGH, R. 2017. Assessment of genetic diversity in bread wheat (Triticum aestivum L.) using RAPD markers. Journal of Applied and Natural Science, 9(3): 1751-1755.

KUMAR, P., YADAV, M. K., SENGAR, R. S., KUMAR, P., KUMAR, M. and SINGH, S. K. 2018. Morphophysiological and biochemical characterization of wheat under the water deficit conditions. Journal of Plant Development Sciences, 10(2): 79-88.

MENKIR, A., GOLDSBROUGH, P. and EJETA, G. 1997. RAPD based assessment of genetic diversity in cultivated races of sorghum. Crop Science, 37(2): 564-569.

MOOLENDRA, T. S., MALIK, A. and TANDAN, N. 2018. RAPD based genetic diversity assessment of cowpea. Plant Archives, 18(2): 2383-2388.

PALVE, S. M. and SINHA, M. K. 2005. Genetic variation and interrelationships among fibre yield attributes in secondary gene pool of Corchorus spp. SABRAO Journal of Breeding and Genetics, 37(1): 55-64. 
PERVEZ, M. A., AYUB, C. M., KHAN, H. A., SHAIHD, M. A. and ASHRAF, I. 2009. Effect of drought stress on growth, yield and seed quality of tomato (Lycopersicon esculentum L.) Pak. J. Agric. Sci., 46(3): 174-178.

PREVOST, A. and WILKINSON, M. J. 1999. A new system for comparing PCR primers applied to ISSR finger-printing of potato cultivars. Theor. Appl. Genet., 98: 107-112.

DHAR, P., OJHA, D., KAR, C. S. and MITRA, J. 2018. Differential response of tossa jute (Corchorus olitorius) submitted to water deficit stress. Industrial Crops \& Products, 112: 141-150.

PRODHAN, A. K. M. A., RAHMAN, M. L. and HAQUE, M. A. 2001. Effect of water stresses on growth attributes in jute I plant height. Pak. J. Biol. Sci., 4: 128-135.

RAZA, M. A. S., SALEEM, M. F., JAMIL, M. and KHAN, I. H. 2014. Impact of Foliar Applied Glycinbetaineon growth and Physiology of wheat (Triticum aestivum L). under drought conditions. Pak. J. Agri. Sci., 51: 327-334.

ROCHA, E. A., PAIVA, L. V., CARVALHO, H. H. D. and GUIMARÃES, C. T. 2010. Molecular characterization and genetic diversity of potato cultivars using SSR and RAPD markers. Crop Breeding and Applied Biotechnology, 10(3): 204-210.

ROSIELLE, A. A. and HAMBLIN, J. 1981. Theoretical aspects of selection for yield in stress and nonstress environment. Crop Science, 21: 943-946.

ROY, A., BANDYOPADHYAY, A., MAHAPATRA, A. K., GHOSH, S. K., SINGH, N. K., BANSAL, K. C. and MOHAPATRA, T. 2006. Evaluation of genetic diversity in jute (Corchorus species) using STMS, ISSR and RAPD markers. Plant breeding, 125(3): 292-297.

SÁNCHEZ-REINOSO, A. D., LIGARRETO-MORENO, G. A. and RESTREPO-DÍAZ, H. 2020. Evaluation of drought indices to identify tolerant genotypes in common bean bush (Phaseolus vulgaris L.). Journal of Integrative Agriculture, 19(1): 99-107.

SHIWACHI, H., KOMODA, M., KOSHIO, K. and TAKAHASHI, H. 2008. Effect of soil moisture stress on the growth of Corchorus olitorius L. Afr. J. Agric. Res., 4: 289-293.

UFOEGBUNE, G. C., ADEBIYI, G. and ADEKUNLE, A. A. 2016. Determination of Water Use of Three Vegetables; Amaranthus (Amaranthus cruenthus), Jutemallo (Corchorus olitorius) and Celosia (Celosia argentea) at Abeokuta, Nigeria. J. Environ. Anal. Toxico., 6(3): 374.

VIERLING, R. A. and NGUYEN, H. T. 1992. Use of RAPD markers to determine the genetic diversity of diploid, wheat genotypes. Theoretical and Applied Genetics, 84(7-8): 835-838.

WANG, W., XIN, H., WANG, M., MA, Q., WANG, L., KALERI, N. A., WANG, Y. and LI, X. 2016. Transcriptomic analysis reveals the molecular mechanisms of drought-stress-induced decreases in Camellia sinensis leaf quality. Front. Plant Sci., 7: 385.

WILLIAMS, J. G. K., KUBELI, A. R., LIVAK, K. J., RAFALSKI, J. A. and TINGEY, S. V. 1990. DNA polymorphism amplified by arbitrary primers are useful as genetic markers. Nucleic Acids Res., 18: 6531-6535.

YAKOUB, A. R. B., BENABDERRAHIM, M. A. and FERCHICHI, A. 2016. Physiological and agromorphological responses of tossa jute (Corchorus olitorius L.) to drought stress. J. Plant Physiol. Pathol., 4(3): 152.

YOUSSEF, A. F., YOUNES, N. A. and YOUSSEF, M. 2019. Genetic diversity in Corchorus olitorius L. revealed by morphophysiological and molecular analyses. Molecular biology reports, 46(3): 29332940.

Contact information

Abdel-Haleem A. H. El-Shaieny: a.elshaieny@agr.svu.edu.eg 
